\title{
A Historical Study of Political System Reform in the Tang and Song Dynasties
}

\author{
Wang Huayu 王化雨 \\ Associate Professor of History Culture and Tourism College, \\ Sichuan Normal University, Chengdu, Sichuan, China \\ why6o6o@126.com
}

\begin{abstract}
The theory of Tang and Song reform proposed by Naitō Torajirō, commonly known as Naitō Konan at the beginning of the twentieth century, not only is a perspective on the differences between the Tang and Song institutions but, to a large extent, also formed the research model on the history of the Song-dynasty system in Japanese research on the history of political institutions. Since the 199os, the topic of Tang and Song reform was introduced to China, but it did not bring any new ideas to the study of Chinese history, nor did it promote reflection on previous research ideas or methods. The historical transformation in the Tang and Song dynasties is, indeed, worthy of attention from historians, but it needs to be done by combining the discussion of Tang and Song reform with the study of political institutional history, avoiding the various existing paradigms in theories on Tang and Song reforms. We must expand the research horizon, placing importance on the restoration of historical reality and referring to the perspectives of "change" and "continuity" rationally, thus allowing for a true breakthrough in Tang and Song historical studies.
\end{abstract}

\section{Keywords}

Naitō Konan - political history - system reform - Tang and Song reform - Tang and Song reform theory

At the beginning of the twentieth century, the Japanese scholar Naitō Konan 內 藤湖南 [Naitō Torajirō, 1866-1934] began a discussion about social transformation in Tang [618-907] and Song [96o-1279] dynasties, after which research on 
Chinese history in Japan was mostly influenced by this discourse, most prominently the historical study of political institutions. Since the 199os, researchers on the history of Chinese institutions have increasingly joined the discussion on the transformation in the Tang and Song dynasties. Therefore, it is necessary to reflect carefully on the relationship between the academic discourse on the changes in Tang and Song dynasties and the history of political institutions and explore how to combine the two better to promote progress in research.

Naitō Konan's exposition on the transformation in the political institutions of the Tang and Song dynasties propounds his theory on Tang and Song reforms. He viewed the Tang dynasty as the end of an aristocratic political system and the Song dynasty as the beginning of a monarchical dictatorship. Before and during the Tang dynasty, the emperor shared political power only with those aristocratic families, and the aristocratic families could even dismiss the emperor. In the Song dynasty, the aristocratic families declined, and political power was held entirely by the emperor. The emperor's position was thus consolidated, and he could control officials at will. The political system with the emperor holding full power began to develop in the Song dynasty and was completed in the Ming [1368-1644] and Qing [1616-1911] dynasties. ${ }^{1}$

Naitō Konan was not the first scholar to discuss the differences between the Tang and Song polities. His substantial contribution is in sorting out some of the most critical phenomena from various changes, taking a holistic look at Chinese politics and even overall development of Chinese society. Moreover, his comparison of Tang and Song politics provided later scholars with a framework for understanding Song-dynasty politics. His discussion on the differences between Tang and Song dynasties in their political institutions, and dictatorship by the emperor in the Song dynasty, set the direction of research by later researchers. His method of summarizing the essential characteristics of the two dynasties by comparing Tang and Song polities was mostly inherited by his fellow researchers. The topic of Tang and Song reform has become the basis for discussion and exchange among scholars. Naitō Konan's analysis of

1 Naitō Konan 內藤湖南, “Gaikatsuteki Tō Sō jidai kan 概括的唐宋時代觀 [A General View of the Tang and Song Dynasties]," Rekishi to chiri 歷史と地理 9, no. 5 (1922). A Chinese version is included in Liu Junwen 劉俊文, ed., and Huang Yuese 黃約瑟, trans., Riben xuezhe yanjiu zhongguo shi lunzhu xuanyi 日本學者研究中國史論著選譯 [Translations of Selected Works by Japanese Scholars on Chinese History] (Beijing: Zhonghua shuju, 1992), 1.10-18. 
the transformation in the Tang and Song dynasties, to a large extent, is said to have created the basic model for the study of political history of the Song dynasty in Japan.

Miyazaki Ichisada 宮崎市定 [1901-1995] not only inherited Naitō Konan's theory but also made it more detailed and in-depth. He pointed out that the Song emperor was able to exercise dictatorship not through his personal ability but also because of the political system. The key point is that changes in the government structure in the Tang and Song dynasties placed various government agencies under the direct command of the emperor. The emperor contacted bureaucrats directly through memorials to understand the political situation and to issue instructions, thus he held power in his own hands. ${ }^{2}$ These expositions further clarified the connotation of "monarchical dictatorship" and opened up many new discussions in academic circles.

Under the influence of Miyazaki Ichisada, Japan made great progress in the study of the Song political system. Historians such as Tomi Saeki 佐伯富 [1910-2006], Kaoru Umehara 梅原郁 [1934-2020], and Toshikazu Araki 荒木敏一[1911-1996] conducted many detailed empirical studies individually, on issues directly related to "monarchical dictatorship" through the emperor's eyes and ears, the bureaucratic system, and the imperial examination system. On this basis, the political transformation of Tang and Song dynasties was further discussed. ${ }^{3}$ These groundbreaking analyses not only enriched and perfected the existing theory on Tang and Song reform but also advanced understanding of the Song-dynasty political system in academic circles.

The academic achievements of researchers in this period not only benefited directly from Naitō Konan's theory on Tang and Song reform but, at the same time, were also constrained by it. Their selection of topics tended to focus on those that were considered to be clearly related to this reform, which framed the directions of their research. When analyzing the specific system changes,

2 Miyazaki Ichisada 宮崎市定, “Dongyang de jinshi 東洋的近世 [East Asia's Early Modern Age]," in Riben xuezhe yanjiu Zhongguo shi lunzhu xuanyi , 1.153-241; idem, "Songdai guanzhi xushuo: Songshi zhiguanzhi de dufa 宋代官制序說: 宋史職官志的讀法 [The Preface to the Official Institutions of the Song Dynasty: How to Read the Official Chronicles of Song History]," trans. Yu Zhijia 於志嘉, Dalu zazhi 大陸雜誌 78, nos. 1-2 (1989).

3 Tomi Saeki 佐伯富, “Lun songdai de huangchengsi 論宋代的皇城司 [On the Imperial City Department of Song Dynasty]," in Riben xuezhe yanjiu zhongguoshi lunzhu xuanyi 日本學 者研究中國史論著選譯 [Selected Translations of Japanese Scholars' Research on Chinese History], ed. Liu Junwen 劉俊文, trans. Suo Jieran 索介然 (Beijing: Zhonghua shuju, 1993), 5.337-69; Kaoru Umehara 梅原郁, Sodai kanryo seido kenkyu 宋代官僚制度研究 [Research on the Bureaucratic System in Song Dynasty] (Kyoto: Dohosha, 1985); Toshikazu Araki 荒木 敏一, Sodai kakyo seido kenkyu 宋代科舉制度研究 [Research on the Imperial Examination System in Song Dynasty] (Kyoto: Dohosha, 1969). 
they often overemphasized the systemic transformation between the Tang and Song dynasties but insufficiently revealed systemic continuity between the dynasties. When making overall comparisons, they paid more attention to factors such as regulatory systems and institutional mechanisms that directly highlighted differences, while paying little attention to complicated and subtle conditions, such as the actual operation of the system. When interpreting the background of systemic transformation, they inevitably stuck to a transition from "aristocratic politics" to "monarchical dictatorship," which sometimes made the interpretations look formal and empty. These shortcomings, to a certain extent, contributed to the emergence of later research ideas that broke through the theory on Tang and Song reform.

In the 1980s and 1990s, two generations of Japanese political history researchers, represented by Teraji Jun 寺地遵 and Hirata Shigeki 平田茂樹, began to seriously reflect on the political history of the Song dynasty under the influence of the theory on Tang and Song reform. They pointed out that, in previous studies, scholars had used too many research approaches that relied on theoretical types to highlight the political differences between the Tang and Song dynasties, paying too much attention to static analysis and the description of government agencies and legal institutions but seldom discussing state consciousness and the process of policy formation. To rectify this shortcoming, they successively proposed new ideas, such as "political process" and "political space." They believed that the process of forming Song-dynasty national policy should be analyzed from a dynamic perspective, the actual roles that various political figures played in this process, and the relational network among them - in particular, the "fields" of various government affairs in the Song dynasty should be studied in depth. ${ }^{4}$

Teraji Jun and Hirata Shigeki therefore captured the shortcomings of the theory of Tang and Song reform, which pays too much attention to formal comparisons and simplifies historical complexity and offers academics a new perspective from which to observe the Song political system. They urged scholars to pay more attention to the actual operation of political power carried out within the framework of Song system, which was restricted by a variety of complex factors. At the same time, their thinking also opened up new topics

4 Teraji Jun 寺地遵, Nansong chuqi zhengzhishi yanjiu 南宋初期政治史研究 [A Study of Political History in the Early Southern Song Dynasty], trans. Liu Jingzhen 劉靜貞 and Li Jinyun 李今芸 (Taipei: Daoxiang chubanshe, 1995); Hirata Shigeki 平田茂樹, “Riben songdai zhengzhishi yanjiu shuping 日本宋代政治史研究述評 [A Review of the Research on the Political History of the Song Dynasty in Japan]," in Songdai zhidushi yanjiu bainian 宋代 制度史研究百年 [A Hundred Years of Research on System History of Song Dynasty], ed. Bao Weimin 包偉民 (Beijing: Shangwu yinshuguan, 2004). 
for academic study, such as decision-making activities, administration of documents, and systemic space. Thereafter, Japanese scholarship on Song history produced a series of works with topics and methods that are consistent with these lines of thinking, which have greatly enriched people's understanding of Song politics.

It should also be noted that the research by Teraji Jun, Hirata Shigeki, and others have not completely escaped the influence of the theory on Tang and Song reform: the theory of "political process" originated directly in Miyazaki Ichisada's argument about the direct contact between the Song-dynasty monarch and his officials; the core elements in Naitō Konan's theory, such as "monarchical dictatorship," were also inherited by them. In addition, in his research, Hirata Shigeki noted that the system operations should be observed from a micro and dynamic perspective, but to some extent he still followed Naitō Konan, Miyazaki Ichisada, and others, who used a comparative method to summarize the essential characteristics of the political system over a certain period, so Hirata Shigeki's thesis still has the weakness of emerging from a generalization more than a detailed analysis. To some extent, a new tendency toward theoretical types appeared.

In summary, what Naitō Konan's theory on Tang and Song reform gave the Japanese political history not only is a perspective on the differences between the Tang and Song institutions but also considerably shaped the research model of Song-dynasty history. Even scholars who wanted to go beyond the theory on Tang and Song reform did not completely escape the influence of this framework. When reviewing the theory on Tang and Song reform, Chinese researchers developed deeper reflections on the positive and negative impacts of the theory as a model.

2

Since the mid-twentieth century, some Chinese scholars-such as Qian Mu 錢穆 [1895-1990], Sun Guodong 孫國棟 [1922-2013], Zhu Ruixi 朱瑞熙, Zhang Bangwei 張邦煒, Qiu Tiansheng 邱添生, Liu Jingzhen 劉靜貞, and Zhao Yule 趙雨樂—have discussed the reforms in the political system in the Tang and Song dynasties. Some of their views, such as their understanding of the monarchy in the Song dynasty, are consistent with those of the Japanese scholars. Although most Chinese scholars have pointed out the differences between the Tang and Song political institutions, unlike the Japanese scholars, they regarded them mostly as changes in degree, rather than as essential transformations. 
In the selection of topics and research methods, these Chinese scholars also often had their own approaches. For example, Zhang Bangwei's exposition on the characteristics of the Song dynasty's having "no inner court" and "no internal strife," and Liu Jingzhen's analysis of the influence of the emperors' character on the formation of "monarchical dictatorship" in the early Song dynasty revealed history that had not been paid enough attention in the past. These perspectives were very fresh.

However, because of the influence of various factors, in general, before the 199os academic discussions about the social transformation in the Tang and Song dynasties focused on socioeconomic and cultural aspects. After the 199os, many treatises on the transformation of the Tang and Song institutions emerged. ${ }^{5}$ This situation is related, on the one hand, to the systematic translation of overseas treatises on the theory on Tang and Song reform since the 198 os and, on the other hand, to increasing academic exchanges on the Tang and Song dynasties. In addition, the concern about the reform of the Tang and Song dynasties also reflects that, after the 199os, political historians wanted to go beyond the previous limitations from paying too much attention to specific issues and established a wider perspective, thereby enhancing the academic value of political history.

Chinese scholars' discussions on the transformation in the Tang and Song institutions have revealed many differences between the two regimes and have helped us develop a better understanding of their characteristics. At the same time, and to a large extent, we have a more comprehensive understanding of the overall development of a system to avoid some misunderstanding caused by arguing about one particular dynastic system alone. In addition, we can also offer a clearer picture of a certain dynasty if we look at the transformation of the entire system.

More importantly, through the research on the Tang and Song dynasties, some scholars unearthed the "intangible" factors hidden under the "tangible" regulatory system, which had an important impact on the transformation of the political system. For example, Deng Xiaonan 鄧小南, Liu Houbin

5 Liu Houbin 劉後濱, Tangdai zhongshu menxia tizhi yanjiu 唐代中書門下體制研究 [A Study on the System of Zhongshu Menxia in Tang Dynasty] (Jinan: Qilu shushe, 2004), can be regarded as the most in-depth study of the Tang and Song system reforms in the field of Chinese system history. Wu Zongguo 吳宗國, ed., Shengtang zhengzhi zhidu yanjiu 盛唐 政治制度研究 [A Study on the Political System of the Prosperous Tang Dynasty] (Shanghai: Shanghai cishu chubanshe, 2003), also has high reference value. Huang Zhengjian 黃正建, ed., Zhongwantang shehui yu zhengzhi yanjiu 中晚唐社會與政治研究 [Social and Political Studies of the Middle and Late Tang Dynasty] (Beijing: Zhongguo shehui kexue chubanshe, 2006), has likewise published many related articles in the collection. 
劉後濱, Li Jinxiu 李錦繡, and others wrote individual in-depth discussions on the development trends and context of the system of selecting civil officials, the central administrative body, and government operations during the Tang and Song dynasties. ${ }^{6}$ These "trends" and "contexts," the more specific systemic changes, can help us understand the transformative trajectory of the Tang and Song dynasties at a deeper level.

However, it should also be noted that the current discussions on Tang and Song reform in Chinese political history still have vast limitations, first, in the selection of topics. Many researchers have just traced a certain system they have studied in the past, either from the Tang dynasty to the Song dynasty, or from the Song dynasty to the Tang dynasty. Inspiring new points of discussions have yet to be raised.

Second, how precisely should we understand the Tang and Song institutional transformation? Researchers have often listed the differences and changes in the Tang and Song institutions, especially the system innovations in the Song dynasty. However, among the various differences and changes, which are substantial, and which are stylistic? And what are the differences in their importance in political transformation? The writings of the researchers are often vague. In addition, some institutional changes pointed out by the researchers, such as the shift in the main supervisory system of the Tang and Song dynasties from the emperors to prime ministers and officials, did not receive sufficient empirical evidence to support the claims. They seem to be "custom-made" for an existing historical view-for example, the strengthening of Song-dynasty imperial power. This situation makes it difficult for us to form a truly clear understanding of the systemic transformation.

Third, how should the relationship between systemic reform and other factors be analyzed? Some works have detailed explanations about the transformation of a certain type of system in the Tang and Song dynasties, but there is often a lack of discussion about its relationship with other political and social changes. For example, the essays that analyze the changes in supervisory organs in the Tang and Song dynasties often do not involve changes in the administrative system at the time, making it difficult for us to see the actual significance of the changes in supervisory organs for government operations

6 Deng Xiaonan 鄧小南, Songdai wenguan xuanren zhidu zhucengmian 宋代文官選任 制度諸層面 [Various Levels of the Selection System of Civil Officials in Song Dynasty] (Shijiazhuang: Hebei jiaoyu chubanshe, 1993); Liu Houbin, Tangdai zhongshu menxia tizhi yanjiu; Li Jinxiu 李錦繡, “Tang houqi de guanzhi: Xingzheng moshi he xingzheng shouduan de biange 唐後期的官制: 行政模式和行政手段的變革 [The Official System in the Late Tang Dynasty: The Reform of Administrative Model and Means]," in Zhongwantang shehui yu zhengzhi yanjiu. 
and the specific factors that affect those changes, and they only summarized it using a general argument, such as "the strengthening of autocratic imperial power."

Some researchers have realized that systemic changes are related to other political and social transformations, but few practical discussions have occurred on where exactly the connection is and how it formed. In particular, when scholars try to analyze the macro reforms at the political and social levels from some micro system changes, their analysis is often not convincing. For example, when analyzing the Tang and Song administrative system of local officials, researchers first assumed that a major shift had occurred from "aristocratic politics" to "bureaucratic politics" during the Tang and Song dynasties. Then they pointed out that the status and treatment of the local officials in the Tang and Song dynasties had significantly declined, which proved that the aristocratic air of Tang and Song officials weakened. These limitations make it difficult for us to investigate deeper social changes through systemic changes.

These deficiencies are largely due to certain inherent deficits in previous studies on political history-for example, lacking awareness of the problem; paying more attention to diachronic system causes, but ignoring the various synchronic factors that have a direct impact on the system in a specific period; and researchers often have preconceptions due to their habitual ignorance. ${ }^{7}$ These situations reveal that most researchers on the Chinese political history have not reflected on previous research ideas and methods after being introduced to the topic of the Tang and Song reform. It can be said that the discussion of Tang and Song Reform has not actually brought many new ideas to the field of Chinese Tang and Song system history. Most researchers just "embed" their previous research into a more influential academic framework, thereby adding "theoretical atmosphere" to their research, trying to give their work more academic significance. ${ }^{8}$ In the current study of the system history

7 Bao Weimin 包偉民, “Zouxiang zijue: Guanyu shenru tuozhan zhongguo gudai zhidushi yanjiu de jige wenti 走向自覺: 關於深入拓展中國古代制度史研究的幾個問題 [Toward Consciousness: Several Questions about Deepening the Research on the History of Ancient Chinese Systems]”; Deng Xiaonan 鄧小南, “Zouxiang 'huo' de zhidushi: Yi songdai guanliao zhidushi weili de diandi sikao 走向“活”的制度史——以宋代官僚制度史為例的點滴思 考 [Toward a 'Living' System History: A Little Thought about the Bureaucratic System History of Song Dynasty as an Example]"; Li Li 李立, "Songdai zhengzhi zhidushi yanjiu fangfalun pipan 宋代政治制度史研究方法論批判 [Criticism on the Research Methodology of the History of Political System in Song Dynasty]"—all in Bao Weimin, Songdai zhidushi yanjiu bainian.

8 Zhang Guogang 張國剛, “Gaige kaifang yilai tangshi yanjiu ruogan redian wenti shuping 改革開放以來唐史研究若干熱點問題述評 [A Review of Several Hot Issues in Tang History Research since Reform and Opening Up]," Shixue yuekan 史學月刊, no. 1 (2009). 
of Tang and Song dynasties, some scholars have paid attention to this issue, and have begun to consciously update their research questions and methodologies, reflect on the perspectives and approaches of existing research, and learn from and draw on the research results and experiences of other fields. ${ }^{9}$ These "reflections," "consciousness," and "learning," if they can be accumulated continuously, should enable real breakthroughs in research.

Finally, the author would like to put forward some preliminary ideas on how to better combine the discussion of Tang and Song Reform with the study of political system history.

First, the research horizon should be expanded. When discussing Tang and Song Reform, one should not only examine the various changes that occurred in different phases of Tang and Song dynasties, but also analyze the significance of these changes in the development of the entire society. It is necessary to put various changes in the context of social transformation and analyze the actual connections among these factors. As far as the system history is concerned, there should be sufficient consideration for the multiple motivations that promote the system change, as well as a more detailed analysis of the complexity of system transformation consequences. The system transformation can be regarded as a dynamic process composed of multiple links. On this basis, combining with the social background of each link, one can actually analyze the political, economic, cultural, and other factors, to see at what level and to what extent they have affected the system transformation. In addition, it should also be combined with other political and social reforms, and gradually analyze how the system reform has produced different effects with the contribution of various factors. As such, it is expected to break through the previous limitations of "debating about the system alone."

It should also be noted that when discussing Tang and Song Reform, one should use it as an entry point to consider the transformative stages of the entire ancient Chinese history. For the selection of topics, researchers should consciously expand the time period and not limit to "Tang and Song," or "during Tang and Song." Some system transformations within Song dynasty, such

9 Deng Xiaonan, "Zouxiang 'huo' de zhidushi”; Liu Houbin, Tangdai zhongshu menxia tizhiyanjiu. These works reflect the in-depth thinking of system history researchers in their research perspectives and methods. 
as the restructuring of Yuanfeng 元豐 [1078-1085], can be further discussed in the context of a longer period of time. And, for example, did the system structure and power operation mode created by Tang and Song Reform continue in Ming and Qing dynasties? Did Ming and Qing dynasties inherit the system legacy created by Tang and Song Reform, or the system factors left over by Jin [1115-1234] and Yuan [1206-1368] dynasties? Such questions should receive attention so as to clarify Tang and Song system reform position in the entire Chinese history.

Second, it should be noted that "Tang and Song reform theory" is not the same as Tang and Song Reform. The latter is historical facts, whereas the former is the predecessors' views on historical facts, which may not always coincide with the historical facts. Holding the predecessors' opinions is bound to be difficult for us to form a deep understanding of the true history. Therefore, while drawing lessons from the existing "Tang and Song Reform Theory," one should also "defamiliarize" it. To prevent preconceptions while conducting a comparative study of Tang and Song institutions, one should not accept the general conclusions of the predecessors before their own analysis of empirical evidences. For predecessors' presuppositions and logical starting points, such as political power has a strong traction for social transformation, and so on, these should be differentiated and analyzed based on historical facts to discover the blind spots in their discourses and to break through the established theories. We can use the research approaches pioneered by predecessors as a reference, but it is inappropriate to imitate them without thinking. For example, the view of "monarchical dictatorship" reminds us that we can analyze the transformation of Tang and Song political institutions from the way the monarch exercised power. However, in terms of specific research objects, one should combine the political facts at the time to develop new discussion points, such as daily administrative operations, government documents operation mode, and so on. For the use of the terms such as "monarchical dictatorship," it is also necessary to reflect on this kind of "archeological knowledge." In short, "Tang and Song Reform Theory" can be used for reference indeed, but we must not treat it as a self-evident prerequisite, nor confuse it with the transformation of Tang and Song history itself.

Third, when we have much knowledge about the results of Tang and Song system reform, it is necessary to strengthen the reform process analysis, and avoid the "film-rewinding" approach that reverses the process based on the results. In the system reform, there are bound to be some links or transformed branches that seem to have little relationship with the final result. These elements often reflect changes in the political society and we should not ignore 
them. Meanwhile, it is inappropriate to assume the mentality and motivation of politicians at the time based on today's understanding of the results of the reform. Instead, one should combine with the specific situation and earnestly consider why people made specific adjustments to the system at the time.

Finally, "reform" should not be considered as the only perspective to observe Tang and Song institutions. It should be noted that there is not only reform but also continuation between the two dynasties. Before careful analysis, one should not form a too strong "direction" so as to exaggerate or even "create" some differences that may not exist between Tang and Song. It should also be noted that whether various specific system changes reflect "break" or "continuity" sometimes depends on the questions we raise and the angle of observing the questions. Most system phenomenon considered to reflect "reform" when viewed from a different angle might reflect some kind of "continuity." In addition, when Tang and Song institutions have undergone major changes, what kind of political mentality and historical concept of the later generations are reflected in the theory of "Song inherited Tang system" [Song cheng Tangzhi 宋承唐制]? All these questions are worth pondering.

In summary, the historical transformation in Tang and Song dynasties are indeed worthy of attention by system history researchers, but one should not be limited to the various existing "Tang and Song Reform Theories." Instead, we should expand our thinking and open new paths before achieving something. (This article was originally published in Zhongguo shi yanjiu 中國史研究 [Journal of Chinese Historical Studies], no. 1 [2010]: 31-36.)

\section{Translated by Donia Zhang}

\section{Works Cited}

Bao Weimin 包偉民, ed. Songdai zhidushi yanjiu bainian 宋代制度史研究百年 [A Hundred Years of Research on System History of Song Dynasty]. Beijing: Shangwu yinshuguan, 2004 .

Deng Xiaonan 鄧小南. Songdai wenguan xuanren zhidu zhucengmian 宋代文官選 任制度諸層面 [Various Levels of the Selection System of Civil Officials in the Song Dynasty]. Shijiazhuang: Hebei jiaoyu chubanshe, 1993.

Huang Zhengjian 黃正建, ed. Zhongwantang shehui yu zhengzhi yanjiu 中晚唐社會與 政治研究 [Social and Political Studies of the Middle and Late Tang Dynasty]. Beijing: Zhongguo shehui kexue chubanshe, 2006. 
Kaoru Umehara 梅原郁. Sodai kanryo seido kenkyu 宋代官僚制度研究 [Research on the Bureaucratic System in the Song Dynasty]. Kyoto: Dohosha, 1985.

Liu Houbin 劉後濱. Tangdai zhongshu menxia tizhi yanjiu 唐代中書門下體制研究 $[A$ Study on the Zhongshu Menxia System in the Tang Dynasty]. Jinan: Qilu shushe, 2004. Liu Junwen 劉俊文, ed. Riben xuezhe yanjiu zhongguoshi lunzhu xuanyi 日本學者研 究中國史論著選譯 [Translations of Selected Works by Japanese Scholars on Chinese History], vols. 1 (trans. Joseph Wong) and 5 (trans. Suo Jieran). Beijing: Zhonghua shuju, 1992, 1993.

Miyazaki Ichisada 宮崎市定. “Songdai guanzhi xushuo: Songshi zhiguanzhi de dufa 宋代官制序說：宋史職官志的讀法 [The Preface to the Official System of the Song Dynasty: How to Read the Official Chronicles of Song History]," translated by Yu Zhijia 於志嘉. Dalu zazhi 大陸雜誌 78, nos. 1 and 2 (1989): 1-14 and 15-28.

Naitō Konan 內藤湖南. “Gaikatsuteki Tō Sō jidai kan 概括的唐宋時代觀 [A General View of the Tang and Song Dynasties].” Rekishi to chiri 歷史と地理 9, no. 5 (1922): 1-12.

Teraji Jun 寺地遵. Nansong chuqi zhengzhishi yanjiu 南宋初期政治史研究 [A Study of Political History in the Early Southern Song Dynasty]. Translated by Liu Jingzhen 劉靜貞 and Li Jinyun 李今芸. Taipei: Daoxiang chubanshe, 1995.

Toshikazu Araki 荒木敏一. Sodai kakyo seido kenkyu 宋代科舉制度研究 [Research on the Imperial Examination System in Song Dynasty]. Kyoto: Dohosha, 1969.

Wu Zongguo 吳宗國, ed. Shengtang zhengzhi zhidu yanjiu 盛唐政治制度研究 [A Study on the Political System of the Prosperous Tang Dynasty]. Shanghai: Shanghai cishu chubanshe, 2003.

Zhang Guogang 張國剛. “Gaige kaifang yilai tangshi yanjiu ruogan redian wenti shuping 改革開放以來唐史研究若干熱點問題述評 [A Review of Several Hot Issues in Tang History Research since Reform and Opening Up].” Shixue yuekan 史學月刊, no. 1 (2009): 5-29. 